\title{
THE
}

6-7-2014

\section{Overwintering Strategies of Bloom-Forming Ulva Species in Narragansett Bay, Rhode Island, USA}

\author{
Shelby Rinehart \\ Michele Guidone \\ Amanda Ziegler \\ Tanja Schollmeier \\ Carol S. Thornber \\ University of Rhode Island, thornber@uri.edu
}

Follow this and additional works at: https://digitalcommons.uri.edu/bio_facpubs

The University of Rhode Island Faculty have made this article openly available.

Please let us know how Open Access to this research benefits you.

This is a pre-publication author manuscript of the final, published article.

Terms of Use

This article is made available under the terms and conditions applicable towards Open Access

Policy Articles, as set forth in our Terms of Use.

\section{Citation/Publisher Attribution}

Rinehart, Shelby; Guidone, Michele; Ziegler, Amanda; Schollmeier, Tanja; Thornber, Carol. (2014). "Overwintering strategies of bloom-forming Ulva species in Narragansett Bay, Rhode Island, USA." Botanica Marina. 57(4): 337-341. Available at: 10.1515/bot-2013-0122 
Overwintering strategies of bloom-forming Ulva species in Narragansett Bay, RI

Shelby Rinehart ${ }^{1,2}$, Michele Guidone ${ }^{1,3}$, Amanda Ziegler ${ }^{1,4}$, Tanja Schollmeier ${ }^{1,5}$, and Carol Thornber $^{1 *}$

${ }^{1}$ University of Rhode Island, Department of Biological Sciences, Kingston, RI 02881, USA

${ }^{2}$ Present address: San Diego State University, Department of Biology, San Diego, CA 92182, USA

${ }^{3}$ Present address: Sacred Heart University, Department of Biology, Fairfield, CT 06492, USA

${ }^{4}$ Present address: University of Hawaii at Manoa, Department of Oceanography, Honolulu, HI 96822, USA

${ }^{5}$ Present address: University of Alaska Fairbanks, Department of Biology, Fairbanks, AK 99775, USA

*Author for correspondence: thornber@uri.edu, phone: 4018744495 


\begin{abstract}
Temperate coastal estuaries worldwide such as Narragansett Bay, Rhode Island are impacted by seasonal macroalgal blooms (e.g. Ulva) during warm months, while bloomforming macroalgae are rarely encountered during winter. We assessed the ability of distromatic Ulva to overwinter via fragments, recruits, and/or microscopic propagules. We documented: a) small tissue fragments in sediment cores and the water column, b) recruits and microscopic propagules on field-based settlement tiles, and c) production of reproductive propagules, throughout the winter months. Laboratory culturing experiments indicated that both fragments and propagules are viable. Our data indicate that bloomforming overwintering Ulva simultaneously utilize multiple reproductive strategies.
\end{abstract}

Key Words: macroalgal bloom, overwintering, propagules, Ulva

Macroalgal blooms in coastal areas are largely composed of fast-growing species that rapidly utilize resources, including many species in the genus Ulva (Valiela et al. 1997, Guidone et al. 2013, Smetacek and Zingone 2013). Macroalgal blooms have increased in frequency and duration over the past several decades due to several factors, including anthropogenic nutrient inputs (Rosenberg 1985, Nixon 1995, Teichberg et al. 2010). Freefloating macroalgal blooms can have devastating impacts upon the economy of coastal areas by fouling beaches and decreasing the productivity of fisheries. Blooms decrease dissolved oxygen within the water column contributing to hypoxic events, which can result in fish kills, suffocation of benthic fauna, and reduced shellfish recruitment (Deacutis and Oviatt 2004, Thomsen and McGlathery 2006). The ability of macroalgae to form these 
blooms may be associated with their ability to grow vegetatively via fragmentation (e.g., Kamermans et al. 1998), in addition to reproduction via microscopic propagules.

Macroalgal blooms are a common occurrence within Narragansett Bay, Rhode Island, particularly in the shallow areas of the upper bay. Blooms in this system are frequently dominated by the green distromatic species Ulva compressa Linnaeus and $U$. rigida C. Agardh (hereafter referred to collectively as Ulva spp., as tubular Ulva species are not typically as abundant in this system), but can contain at least thirty different species (Guidone and Thornber 2013, Guidone et al. 2013). Blooms occur frequently in the late spring and summer, but are rarely observed in the late fall and winter (Newton and Thornber 2012, Guidone and Thornber 2013). Since Ulva spp. mats do not occur during winter months, Ulva spp. must utilize one or more overwintering strategies that permit them to propagate quickly once suitable environmental conditions return. In other regions, vegetative fragments of Ulva spp. are capable of surviving low temperatures (Zhang et al. 2010) while buried within sediments, which may reduce the impacts of freezing (Kamermans et al. 1998). In addition, Lotze et al. (2000) found that tubular Ulva spp. (formerly Enteromorpha) germlings (recruits) are able to survive the winter attached to hard substrates, leading to an early spring increase in Ulva spp. biomass. Furthermore, Ulva spp. may produce reproductive propagules (spores/zygotes) throughout the winter as a primary overwintering strategy (Liu et al. 2012). Any of these methods may explain seasonal summer ulvoid blooms within Narragansett Bay, RI. Here, we present data on the overwintering abilities of Ulva spp. as vegetative fragments, attached germlings, and reproductive propagules, with implications for the year-round persistence of Ulva spp. 
The mean density of Ulva spp. fragments buried in sediments was $7.13 \mathrm{~m}^{-3} \pm 2.12$ (mean \pm 1 standard error) and did not vary significantly among sites or months $\left(\mathrm{F}_{2,7}=0.47\right.$, $\mathrm{p}=0.64 ; \mathrm{F}_{3,6.4}=2.22, \mathrm{p}=0.18 ;$ Fig. 1). The mean density of Ulva spp. fragments in the water column, averaged across all winter months was $131 \mathrm{~m}^{-3} \pm 40$. The mean length of fragments was $11.6 \pm 5.7 \mathrm{~mm}$ and $55.2 \pm 6.2 \mathrm{~mm}$ (sediment and water column, respectively), although fragments as long as $330 \mathrm{~mm}$ were present. Buried fragments of Ulva compressa and $U$.rigida were healthy; when subsequently cultured in the laboratory for 1.5 weeks (see Fig. 1 legend for culturing details), their biomass remained constant (initial vs. final biomass, $\mathrm{t}_{16}=0.65, \mathrm{p}=0.74$; data were pooled between species, as they did not significantly differ).

We found evidence of Ulva spp. germling recruitment from July through October 2012 on our monthly ('short-term') settlement tiles from Chepiwanoxet, while recruitment was only observed in September 2012 for Oakland Beach (Fig. 2A, B). Although germling biomass did not differ significantly between our two sampling sites or among months (January 2012 - March 2013; $\mathrm{F}_{1,14}=3.05, \mathrm{p}=0.10 ; \mathrm{F}_{14,14}=1.04, \mathrm{p}=0.47$, respectively), there was a significant interaction term $\left(\mathrm{F}_{14,116}=1.88, \mathrm{p}=0.03\right.$; see Table 1 for total algal recruitment). We found no correlation of Ulva biomass with other algal biomass $\left(\mathrm{r}^{2}=\right.$ 0.04), indicating that monthly Ulva recruitment is not linked to the recruitment of other algal species on our tiles.

By contrast, our 'long-term' settlement tiles exhibited much higher biomass of Ulva recruits (Fig. 2C, D; Table 1 for total algal recruitment). For the first tile deployment (deployed in September 2011, removed from January - May 2012), Ulva biomass reached a maximum in April-May 2012 at both sites, although it did not significantly differ between 
sites or among months $\left(\mathrm{F}_{1,4.0086}=1.64, \mathrm{p}=0.27 ; \mathrm{F}_{4,4}=2.10, \mathrm{p}=0.24\right)$. The biomass of Ulva recruits was positively correlated with the biomass of other algal recruits on the tiles $\left(\mathrm{r}^{2}=\right.$ $0.30, \mathrm{p}<0.0001)$

For the second tile deployment (deployed in May 2012, removed from June 2012March 2013), we found relatively low Ulva germling biomass (mean $0.01 \pm 0.005 \mathrm{~g} \cdot 100$ $\left.\mathrm{cm}^{-2}\right)$ that again did not significantly differ between sites or among months $\left(\mathrm{F}_{1,10.68}=3.63 \mathrm{p}\right.$ $=0.08 ; \mathrm{F}_{9,9}=0.97, \mathrm{p}=0.52$, respectively). For this deployment, the biomass of Ulva recruits was not correlated with other algal recruitment $\left(r^{2}=0.004, p=0.54\right)$. However, when we compare Ulva biomass from the two deployments (only including data from tiles in the field 4 months or more, to standardize among deployments), there was a nearly eightyfold difference in mean Ulva recruit biomass $\left(0.78 \mathrm{~g}\right.$ vs $\left.0.02 \mathrm{~g} \cdot 100 \mathrm{~cm}^{-2}\right)$ between the two deployments $\left(\mathrm{F}_{1,109}=18.67, \mathrm{p}<0.0001\right)$, indicating significant year-to-year variability.

Short-term tiles deployed in the field for one month and then cultured in the laboratory under simulated spring conditions for two months indicated that distromatic Ulva spp. are producing reproductive propagules throughout the winter months, as distromatic blades were present every month. We found no significant differences among months or sites in Ulva recruit density ( $p>0.05$ for both; mean of $1.4 \pm 0.65$ recruits $\cdot 100$ $\mathrm{cm}^{-2}$; see Fig. 2 legend for methods).

Overall, our data indicate that Ulva spp. within Narragansett Bay utilize multiple mechanisms to survive the winter. Our data show that Ulva spp. are able to successfully overwinter as buried fragments, and we found that fragments are also present in the water column during the winter. Additionally, sediment fragment densities were consistent 
throughout the winter months and among our three sample sites, although the lack of statistical significance among months may be due, in part, to high variability in fragment density and/or low replication. As our cultured fragments were viable throughout the winter months, in this system, Ulva spp. fragments can survive winter conditions and proliferate in the spring months when Ulva spp. blooms commence. These fragments may act in a similar way to terrestrial 'seed banks', providing a mechanism for species' persistence in years where there is reduced reproductive propagule production and/or recruit survival (Fenner and Thompson 2004).

Our settlement tile data support previously observed patterns of Ulva spp. biomass in Narragansett Bay, RI (Guidone and Thornber 2013). On long-term tiles, Ulva spp. reached maximum biomass from March through May 2012. By contrast, our short-term tiles show increased recruitment from mid summer to early fall 2012 at Chepiwanoxet, and in September 2012 at Oakland Beach. These patterns suggest that Ulva spp. are overwintering as microscopic germlings upon the benthos, likely settling during the late summer or early fall and initiating growth in the early spring when light levels, nutrient levels, and temperature are high enough to support growth (Lotze et al. 2000, Liu et al. 2012). This explains the overall lack of Ulva spp. biomass throughout the winter months and the rapidly forming blooms observed in mid spring (Guidone and Thornber 2013).

The decrease in Ulva spp. biomass between May and June 2012 on long-term tiles is likely due to Ulva spp. individuals becoming too large and dislodging from the settlement tiles. These dislodged individuals become free-floating thalli which may fragment, contributing to Ulva spp. bloom formation. 
Our data provide increasing evidence for the multiple strategies that bloom-forming Ulva spp. can employ to survive harsh winter conditions. Macroalgal blooms are recognized as an increasing phenomenon and problem worldwide (Smetacek and Zingone 2013); while numerous environmental factors contribute to bloom formation (Valiela et al. 1997), the strategies that these algae employ during non-bloom periods are also critical to their interannual persistence.

\section{Acknowledgements}

We would like to thank A. Battocletti, E. Bishop, E. Potter, M. McConville, and M. Wands for their help in the field. Funding was provided by the University of Rhode Island Undergraduate Research Initiative and the Stan Cobb Endowment for Marine Biology. This material is based, in part, upon work supported in part by the National Science Foundation EPSCoR Cooperative Agreement \#EPS-1004057 and the State of Rhode Island. This manuscript was substantially improved by comments from M. Dring and an anonymous reviewer. 


\section{References Cited}

Deacutis, C., and C.A. Oviatt. 2004. August 2003 fish kill. 41N: Monitoring Narragansett Bay 3: 10-11.

Fenner, M., and K. Thompson. 2004. The Ecology of Seeds. Cambridge University Press: New York.

Guidone, M., and C.S. Thornber. 2013. Examination of Ulva bloom species richness and relative abundance reveals two cryptically co-occurring bloom species in Narragansett Bay, Rhode Island. Harmful Algae 24: 1-9.

Guidone, M., C.S. Thornber, B. Wysor, and C.J. O'Kelly. 2013. Molecular and morphological diversity of Narragansett Bay (RI, USA) Ulva (Ulvales: Chlorophyta) populations. J. Phycol. 49: 979-995.

Kamermans, P., E.-J. Malta, J.M. Verschuure, L.F. Lentz, and L. Schrijvers. 1998. Role of cold resistance and burial for winter survival and spring initiation of an Ulva spp. (Chlorophyta) bloom in a eutrophic lagoon (Veerse Meer lagoon, The Netherlands). Mar. Biol. 131: 45-51.

Liu, F., S.J. Pang, X.B. Zhao, and C.M. Hu. 2012. Quantitative, molecular and growth analyses of Ulva microscopic propagules in the coastal sediment of Jiangsu province where green tides initially occurred. Mar. Environ. Res. 74: 56-63.

Lotze, H.K., B. Worm, and U. Sommer. 2000. Propagule banks, herbivory and nutrient supply control population development and dominance patterns in macroalgal blooms. Oikos 89: 46-58.

Newton, C., and C. Thornber. 2012. Abundance and species composition surveys of macroalgal blooms in Rhode Island salt marshes. Northeast. Nat. 19: 501-516. 
Nixon, S.W. 1995. Coastal marine eutrophication: a definition, social causes, and future concerns. Ophelia 41: 199-219.

Rosenberg, R. 1985. Eutrophication: the future marine coastal nuisance. Mar. Pollut. Bull. 16: $227-231$.

Smetacek, V., and A. Zingone. 2013. Green and golden seaweed tides on the rise. Nature 504: 84-88.

Teichberg, M., S.E. Fox, Y.S. Olsen, I. Valiela, P. Martinetto, O. Iribarne, E.Y. Muto, M.A.V.Petti, T.N. Corbisier, M. Soto-Jimenez, F. Paez-Osuna, P. Castro, H. Freitas, A. Zitelli, M. Cardinaletti, and D. Tagliapietra. 2010. Eutrophication and macroalgal blooms in temperate and tropical coastal waters: nutrient enrichment experiments with Ulva spp. Global Change Biol. 16: 2624-2637.

Thomsen, M., and K. McGlathery. 2006. Effects of accumulations of sediments and drift algae on recruitment of sessile organisms associated with oyster reefs. Journal of Experimental Marine Biology and Ecology 328: 22-34.

Valiela, I., J. McClelland, J. Hauxwell, P.J. Behr, D. Hersch, and K. Foreman. 1997. Macroalgal blooms in shallow estuaries: Controls and ecophysiological and ecosystem consequences. Limnol. Oceanogr. 42: 1105-1118.

Zhang, X., H. Wang, Y. Mao, C. Liang, Z. Zhuang, Q. Wang, and N. Ye. 2010. Somatic cells serve as a potential propagule bank of Enteromorpha prolifera forming a green tide in the Yellow Sea, China. J. Appl. Phycol. 22: 173-180. 
Table 1: Mean total wet mass (in grams) of all algal germlings upon $100 \mathrm{~cm}^{2}$ settlement tiles $(n=5 /$ treatment/site/date), from January 2012 - March 2013. Empty cells indicate zero algal biomass present; see Fig. 2 legend for method details.

\begin{tabular}{llrll} 
& \multicolumn{2}{c}{ Chepiwanoxet Point } & \multicolumn{2}{c}{ Oakland Beach } \\
Month-Year & Short term & Long term & Short term & Long term \\
Jan.- 2012 & $4 \times 10^{-5}$ & 0.865 & & 0.128 \\
Feb. & & 1.740 & $1 \times 10^{-4}$ & 0.137 \\
Mar. & & 9.037 & & 0.927 \\
Apr. & & 15.190 & & 2.860 \\
May. & & 4.081 & & 3.773 \\
Jun. & $4 \times 10^{-4}$ & $5 \times 10^{-4}$ & $5 \times 10^{-4}$ & $3 \times 10^{-4}$ \\
Jul. & 0.093 & 0.488 & 0.001 & 0.004 \\
Aug. & 0.064 & 2.655 & 0.195 & 0.113 \\
Sep. & 5.368 & 33.694 & 0.377 & 4.181 \\
Oct. & 0.216 & 15.362 & 0.280 & 0.245 \\
Nov. & & 3.229 & $3 \times 10^{-4}$ & 0.116 \\
Dec. & & 3.741 & & 0.242 \\
Jan.- 2013 & & 2.539 & 0.006 & 0.032 \\
Feb. & & 2.194 & $5 \times 10^{-5}$ & 0.707 \\
Mar. & & 0.543 & & $4 \times 10^{-4}$
\end{tabular}




\section{Figure Legends}

Figure 1: Mean density of distromatic Ulva spp. fragments ( \pm one standard error) in sediment core samples from November 2010 - February 2011. $\mathrm{N}=$ six cores $\left(166 \mathrm{~cm}^{3}\right.$ each $)$ were collected monthly at each of three bloom-impacted sites in Narragansett Bay, RI (Warwick City Park, Oakland Beach, and Chepiwanoxet Point -- all in Warwick, RI) during spring low tide. At each site, we laid out two $30 \mathrm{~m}$ transects. Along each transect, we collected one core from $1 \mathrm{~m}$ subtidal, one core at the water line, and one core $9 \mathrm{~m}$ horizontally away from mean lower low water (all cores were collected below the $S$. alterniflora zone). We counted all distromatic Ulva spp. fragments in each core and determined a collective wet mass. Other algal thalli were weighed together, per sample, and we recorded all genera present (fragments were frequently too small for accurate specieslevel designations). A subtidal net sweep $\left(0.08 \mathrm{~m}^{-3}\right)$ was conducted at the same time to quantify suspended Ulva fragments. Ulva fragment viability was determined in January and February 2011. Using filtered seawater, we cultured ten distromatic Ulva spp. fragments (or fewer, depending upon availability, from field collected samples, with an initial size of at least $5 \times 5 \mathrm{~mm}$ ), per month. Fragments were cultured for 1.5 weeks to assess viability, using broad-spectrum growth lamps, on a 16:8 hour light:dark cycle, at $21-22{ }^{\circ} \mathrm{C}$. All data were analyzed using JMP v 10.0 (www.jmp.com).

Figure 2: Mean Ulva spp. density \pm one standard error, on $100 \mathrm{~cm}^{2} \mathrm{PVC}$ settlement tiles. A) short-term tiles at Chepiwanoxet Point; B) short-term tiles at Oakland Beach Cove; C) long-term tiles at Chepiwanoxet Point; D) long-term tiles at Oakland Beach Cove ( $\mathrm{n}=5$ tiles for each tile type/month/location). To test if Ulva spp. overwinter as attached germlings, we deployed tiles covered in Grainger 3M tread medium resilient safety walk at 
Chepiwanoxet and Oakland Beach Cove, Warwick, RI. At each site, 25 'long-term' settlement tiles were placed $30 \mathrm{~cm}$ below mean lower low water in September of 2011 and five were removed each month, starting in January 2012. From December 2011 onward, five additional tiles were placed in the field each month and collected the next month ('short-term' tiles). We quantified the biomass and number of individuals in each genus present on each tile. Settlement tile collection continued until all initial 'long-term' tiles were collected (May 2012). At that time, sixty more long-term tiles were deployed at each site, and processed in an identical manner (due to tile loss from extreme weather events, sampling ended prematurely in March 2013). We assessed Ulva spp. reproductive propagule production from November 2012 - February 2013 by placing five additional settlement tiles in the field at each site, monthly, for 30 days. Tiles were then cultured in the laboratory for two months, with simulated spring water conditions $\left(18-19^{\circ} \mathrm{C}, 22-28\right.$ psu). After two months, all attached germlings were counted and identified to genus on each tile. None of the 'cultured' tiles had visible recruits at the time of field collection. 


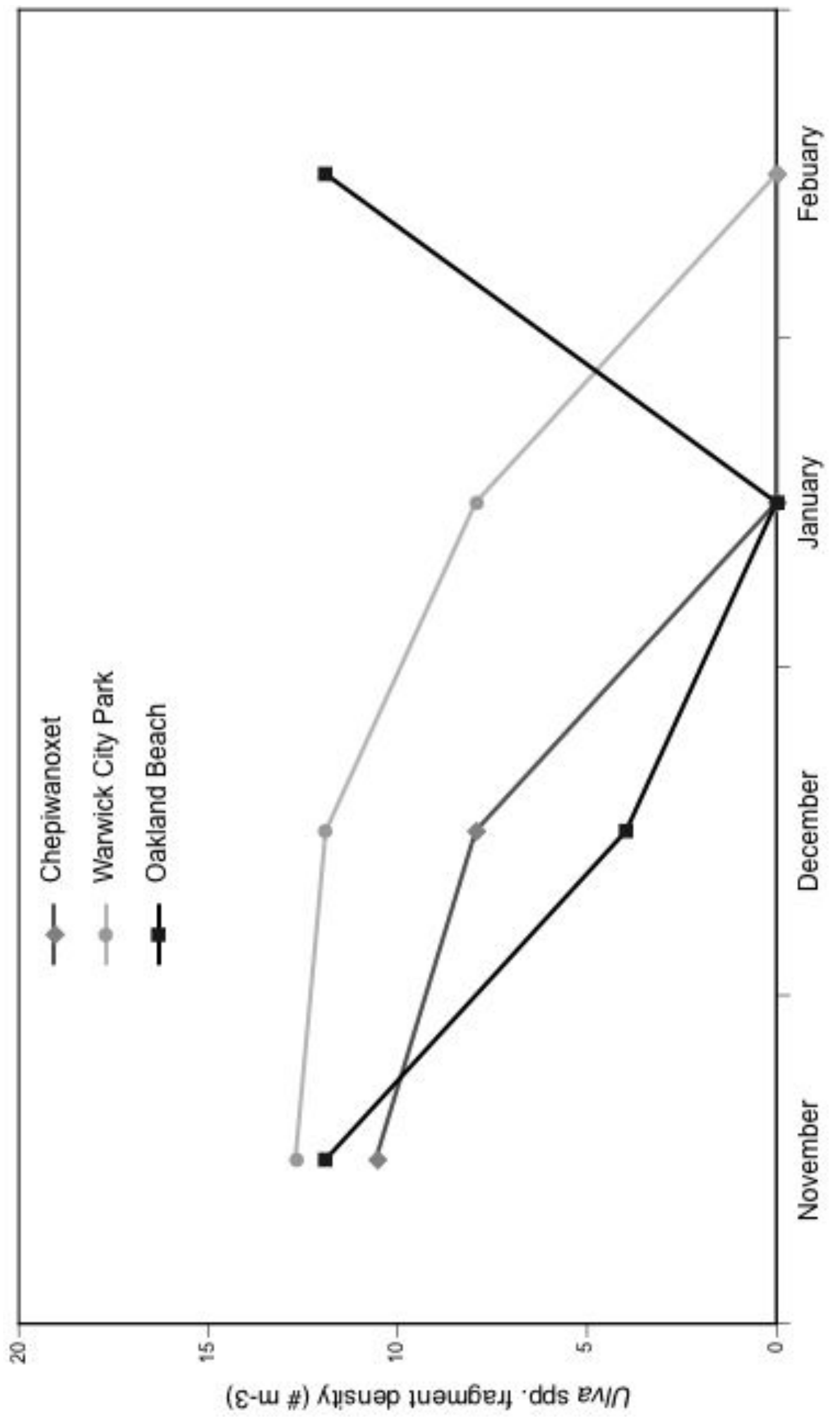



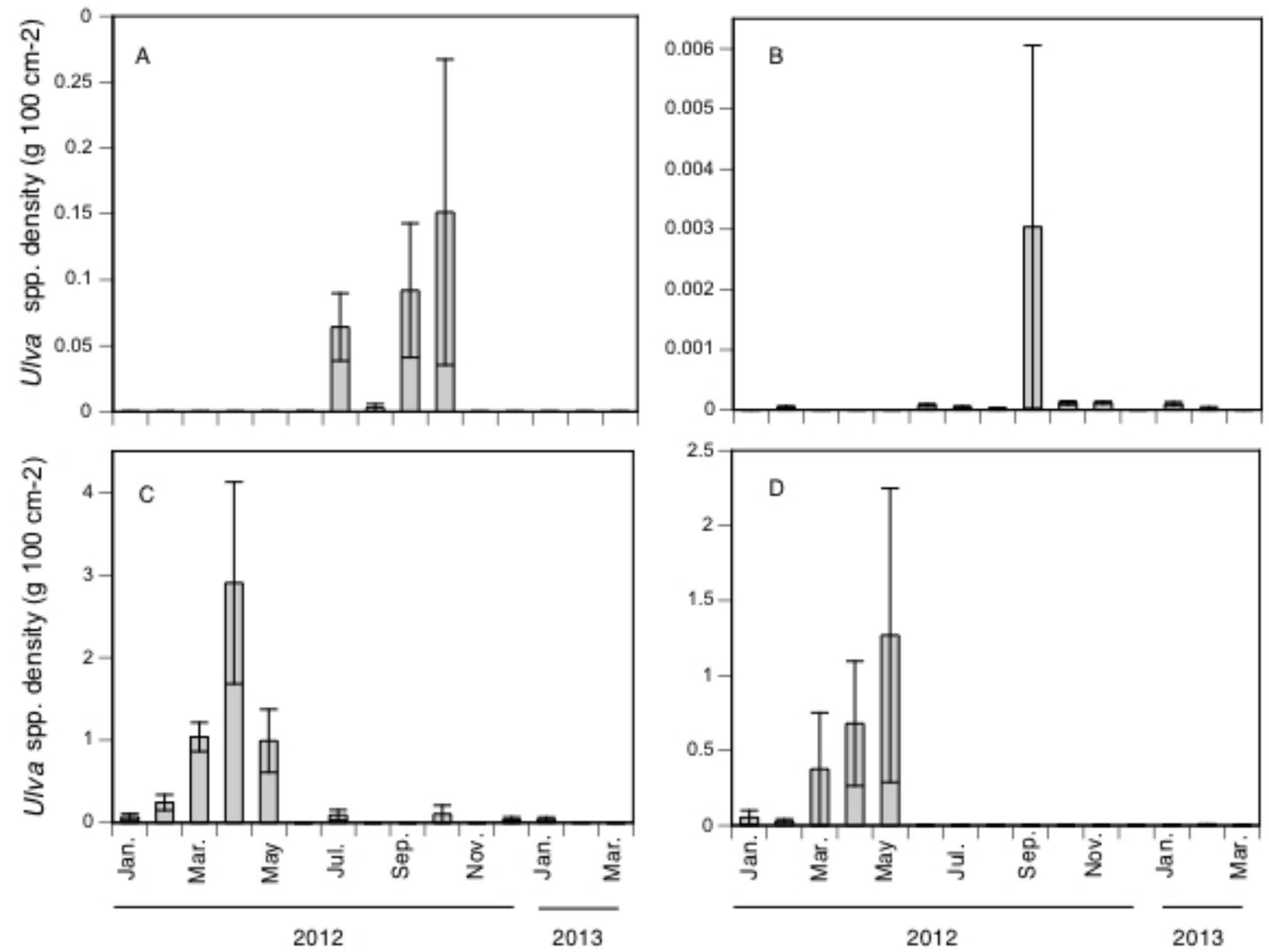